\title{
Perancangan Sistem Informasi Penjualan Berbasis Web Pada Toko BK Ethnic Cloth
}

\author{
Sahat Parluhutan Lumban Batu a,1, ${ }^{\text {, }}$, Ade Surya Budiman ${ }^{\mathrm{b}, 2}$, Nia Nuraeni a,3 \\ a Program Studi Teknik Informatika, STMIK Nusa Mandiri, Jakarta \\ ${ }^{\text {b }}$ Program Studi Teknologi Komputer, FTI-Universitas Bina Sarana Informatika, Jakarta \\ ${ }^{1}$ sahatmarbun147@gmail.com*; ${ }^{2}$ ade.aum@bsi.ac.id; ${ }^{3}$ nia.nne@nusamandiri.ac.id \\ * Penulis Korespondensi
}

\begin{abstract}
BK Ethnic Cloth merupakan perusahaan yang bergerak di bidang industri pakaian. Namun masih menggunakan cara manual, seperti data produk, transaksi penjualan dan laporan penjualan, kemudian di lakukan proses komputerisasi dengan cara memasukankedalam aplikasi pengolah angka yang dimana peluang melakukan kesalahan menjadi lebih besar karena dibutuhkan ketelitian serta waktu yang relative lebih lama. Tujuan dilakukannya penelitian ini adalah untuk merancang sebuah sistem informasi penjualan berbasis web untuk memberikan kemudahan dalam memproses serta menyimpan data-data transaksi penjualan, sehingga kinerja operasional toko akan lebih mudah dalam proses transaksi penjualan. Metode pengembangan sistem yang digunakan adalah Waterfall dengan melakukan studi literatur mengenai sistem kerja website e-commerce, kemudian dilakukan inplementasi perancangan sistem dan desain website $e$-commerce. Sedangkan perangkat lunak dalam pembuatan sistem ini menggunakan bahasa pemrograman PHP dengan framework Code Ignitor, untuk code editor menggunakan Sublime Text 3 dan untuk database menggunakan MySQL. Maka hasil penelitian menunjukan bahwa perancangan sistem informasi penjualan dapat membantu pelanggan mengakses informasi mengenai produk yang dijual dalam melakukan proses pemesanan produk.
\end{abstract}

\section{Pendahuluan}

Seiring dengan perkembangan teknologi di era revolusi industri 4.0 ini perusahaan-perusahaan dipicu untuk menggunakan teknologi untuk tetap bertahan pada persaingan yang semakin ketat dan keras. Internet merupakan sebuah media yang sudah tidak asing bagi kita yang secara umum menjadi alat persaingan antara perusahaan yang satu dengan yang lain. Dampak persaingan tersebut membuat tingkat kompetisi di dunia bisnis semakin tajam, sehingga perusahaan harus dapat beradaptasi dengan perubahan agar dapat bersaing dengan para kompetitornya [1].

Teknologi ini memegang peran yang penting bagi perusahaan-perusahaan yang sedang berkembang maupun yang sudah maju [2]. Salah satu aspek penting dalam perkembangan tekonologi ini yaitu munculnya electronic commerce (e-commerce) di dalam lingkungan bisnis. Dimana electronic commerce (perdagangan eletronik) merupakan kegiatan jual beli barang/jasa atau transmisi dana/data melalui jaringan elektronik, dengan adanya E-commerce dapat memudahkan konsumen untuk melakukan transaksi jual beli tanpa harus datang ketempatnya [3].

Seperti penelitian yang di lakukan sebelumnya [4] pada Newbiestore yang merupakan salah satu usaha penjualan pakaian di daerah Majalengka masih menggunakan sistem konvensional, dimana konsumen harus mendatangi Newbiestore untuk memilih dan membeli produk-produk yang disediakan. Dengan diterapkannya sistem E-Commerce akan dapat memudahkan Newbiestore dalam melakukan promosi penjualan dan mengelola proses transaksi penjualan.

BK Ethnic Cloth merupakan perusahaan yang bergerak di bidang industri pakaian. Namun perusahaan tersebut belum memiliki website toko online (e-commerce). Sistem yang berjalan pada perusahaan 
tersebut masih menggunakan sosial media untuk melakukan penjualan dan promosi. Penjualan BK Ethnic Cloth masih menggunakan cara manual, seperti data produk, transaksi penjualan dan laporan penjualan, kemudian di lakukan proses komputerisasi dengan cara memasukan kedalam aplikasi pengolah angka yang dimana peluang melakukan kesalahan menjadi lebih besar karena dibutuhkan ketelitian serta waktu yang relative lebih lama, hal ini terjadi karena pada BK Ethnic Cloth ini belum mempunyai sistem informasi yang mendukung dalam proses penjualan produk sehingga menjadi kurang efektif dan efisien dalam kinerja perusahaan itu sendiri, dan kurangnya informasi tentang ketersediaan produk kepada konsumen. Dimasa yang sekarang suatu bidang usaha kurang kompetitif jika tidak memiliki sebuah toko online (ecommerce), dengan kata lain perusahaan yang menggunakan teknologi akan lebih mudah bersaingdan dapat meningkatkan keuntungan pada BK Ethnic Cloth di karenakan biaya operasional yang lebih murah.

Berdasarkan latar belakang diatas, penulis akan membuat sebuah website toko online (e-commerce) untuk mempermudah proses penjualan dan promosi. Adapun judul penelitian yang penulis bahas adalah “Perancangan sistem informasi penjualan berbasis web pada Toko BK Ethnic Cloth".

\section{Landasan Teori}

\section{a. Konsep Dasar Sistem Infomasi}

Sistem adalah suatu kumpulan atau himpunan dari unsur, komponen, atau variabel yang terorganisir, saling berinteraksi, saling tergantung sama lain, dan terpadu [5].

Sistem informasi adalah sebuah teknologi informasi yang memilikitujuan untuk menyampaikan informasi. Sistem informasi digunakan oleh semua pengguna teknologi di dalam sebuah kelompok atau organisasi [6].

\section{b. E-Commerce}

E-Commerce (Electronic Commerce) adalah sebuah proses transaksipenjualan barang dan jasa yang terjadi dengan menggunakan alat elektronik, seperti telepon dan internet [7]. E-commerce merupakan bagian dari e-lifecycle yang memungkinkan transaksi jual beli yang dapat dilakukan dari berbagai tempat.

\section{c. Unified Modelling Language (UML)}

Unified Modelling Languange adalah sebuah alat yang digunakan untuk merancang sistem yang berorientasi pada objek. Sebagian besar para perancang sistem informasi menggunakan Unified Modelling Languageuntuk berkomunikasi, menspesifikasikan dan membangun perangkat lunak [8].

\section{d. Entity Relation Diagram (ERD)}

Model ERD adalah suatu bentuk diagram yang berisi kumpulan entitas dan himpunan relasi yang mempresentasikan seluruh objek-objek yang salingberhubungan antara entitas yang ada dengan atributatributnya. ERD memilliki beberapa hubungan pengolahan data seperti hubungan manytomany, onetomany, onetoone [9].

\section{e. XAMPP}

XAMPP merupakan sebuah perangkat lunak yang mendukung banyak sistem operasi. XAMPP terdiri atas program Apache HTTP Serveryang dapat digunakan sebagai server yang berdiri sendiri (localhost), MySQL database yang dapat digunakan sebagai perancangan data, dan dapat menerjemah bahasa yang ditulis dengan bahasa pemrograman PHP dan Perl. Nama XAMPP merupakan singkatan dari X (empat sistem operasi apapun), Apache, MySQL, PHP dan Perl [10].

\section{f. PHP}

PHP adalah bahasa pemrograman yangyang berjalan pada server sitedan dipadukan dengan HTMLupembuatan dan pengembangan sebuah website. PHP merupakan singkatan dari "PHP : Hypertext Preprocessor'. PHP bekerja pada sisi server (server-side HTML-embedded scripting).

PHP dirancangandapat bekerja sama dengan database server dan menampilkan hasil pada web browser sementara proses dijalankan di server[10].

g. MYSQL 
MySQL adalah implementasi sistem manajemen basis data (RDBMS) yang berlisensi GPL (General PublicLicense). Dimana setiap orang bebas untuk menggunakan MySQL. MySQL digunakan untuk perancangandatabaseyang merupakan turunan dari SQL (Structured Query Language).SQL adalah bahasa yang digunakan pada konsep pengoperasian database. Keadaan suatu sistem database (DBMS) dapat diketahui SQLdapat dijalankan dengan memasukkan perintah manipulasi atau mengakses datayang dibuat oleh user maupun program-program aplikasinya. Sebagai salah satu database server, MySQL juga lebih unggul dibandingkan database server lainnya dalam Query data [11].

\section{h. JAVASCRIPT}

JavaScript adalah bahasa pemrograman tingkat tinggi yang disematkan pada kode HTML dan berjalan pada proses sisi klien, sehingga dapat membuat tampilan yang intekatif dan dinamis [12].

i. CSS

Cascading Style Sheet (CSS) merupakan aturan untuk mengendalikan beberapa komponen dalam sebuah web sehingga akan lebih terstruktur [12].

\section{Metode Penelitian}

\subsection{Metode Pengumpulan Data}

Teknik pengumpulan data yang penulis gunakan antara lain sebagai berikut:

a. Observasi

Penulis melakukan observasi secara online pada toko BK Ethnic Cloth untuk menentukan kebutuhan dan data-data yang akan digunakan pada sistem yang akan dirancang.

b. Wawancara

Penulis melakukan wawancara secara online melalui media sosial dengan pemilik toko BK Ethnic Cloth tentang sistem penjualan yang selama ini digunakan.

c. Studi Pustaka

Pada studi pustaka penulis mengumpulkan informasi dari berbagai jurnal dan mencari informasi dari media internet tentang toko online (e-commerce).

\subsection{Metode Pengembangan Sistem}

Metode pengembangan sistem yang penulis gunakan adalah metode SDLC (System development life cycle) dimana konsep dasar dari SDLC yaitu metodologi pengembangan perangkat lunak untuk merancang, mngembangkan dan menguji perangkat lunak berkualitas tinggi [13].

a. Analisis kebutuhan system

Analisis kebutuhan sistem merupakan suatu proses pengumpulan data-data yang akan digunakan sebagai bahan pembuatan sistem informasi serta mengidentifikasi kebutuhan akan informasi.

b. Desain

Desain merupakan proses multi langkah yang berkonsentrasi pada desain pembuatan perangkat lunak termasuk struktur data, arsitektur perangkat lunak, representasi antarmuka dan prosedur pengkodean.

\section{c. Code Generation}

Code generation merupakan penerjamahan sebuah bahasa pemrograman yang dapat dikenali oleh komputer [14]. Dilakukan oleh programmer untuk menterjemahkan transaksi yang diminta oleh user. Dalam pembuatan website ini, penulis menggunakan frameworkCodeignitor 3 sebagai desain dan Mysql sebagai database. Ini merupakan tahapan secara nyata dalam mengerjakan suatu sistem informasi.

\section{d. Testing}

Setelah tahap pengkodean telah selesai maka akan dilakukan tahap testing terhadap sistem yang telah dibuat. Pada tahap testing ini penulis menggunakan Black Boxtesting untuk menemukan kesalahan-kesalahan dan memeriksa fungsional yang terdapat pada sistem [15]. Tujuan dari testing ini adalah untuk menemukan kesalahan dan dapat langsung diperbaiki. 
e. Support

Tahap support (maintenance) merupakan tahapan dimana sistem yang telah lolos uji coba akan diserahkan kepada pemilik pasti akan mengalami perubahan. Pemilik dan pengembang sistem harus melakukan pendekatan sistem untuk mencari solusi jika masih ditemukan keselahan akibat perubahan yang terjadi dan jika pemilik menginginkan pengembangan fungsional dari sistem.

\section{Hasil dan Pembahasan}

\subsection{Perancangan Pemodelan Sistem}

a. Use Case Diagram daftar User dan Checkout Member.

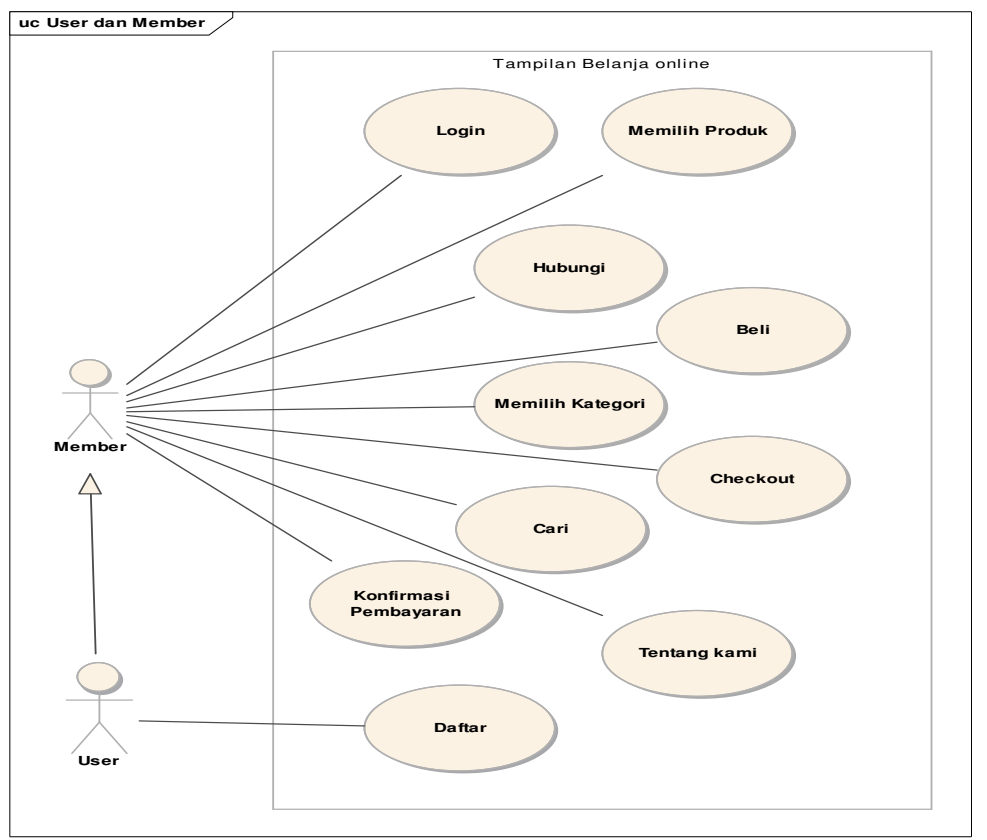

Gambar 1. Use Case Diagram daftar User dan Checkout Member

b. Use Case Diagram Penjualan Online Halaman Admin

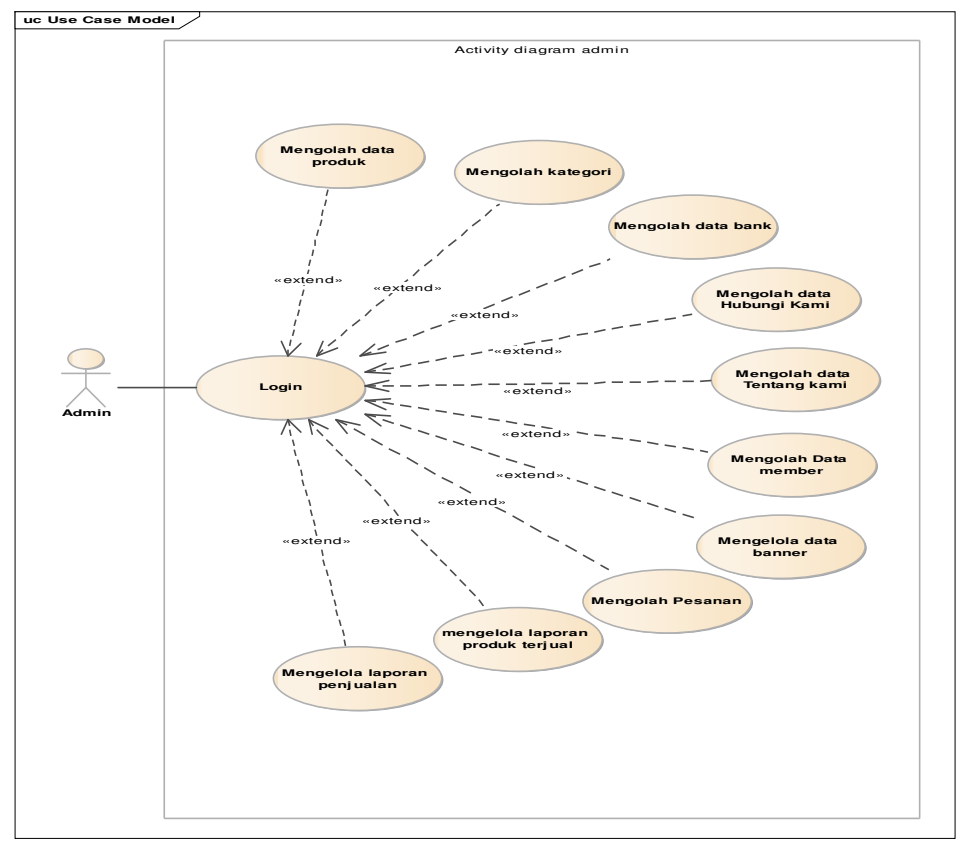


Fig. 1.Use Case Diagram Halaman Admin

c. Activity Diagram Login Member

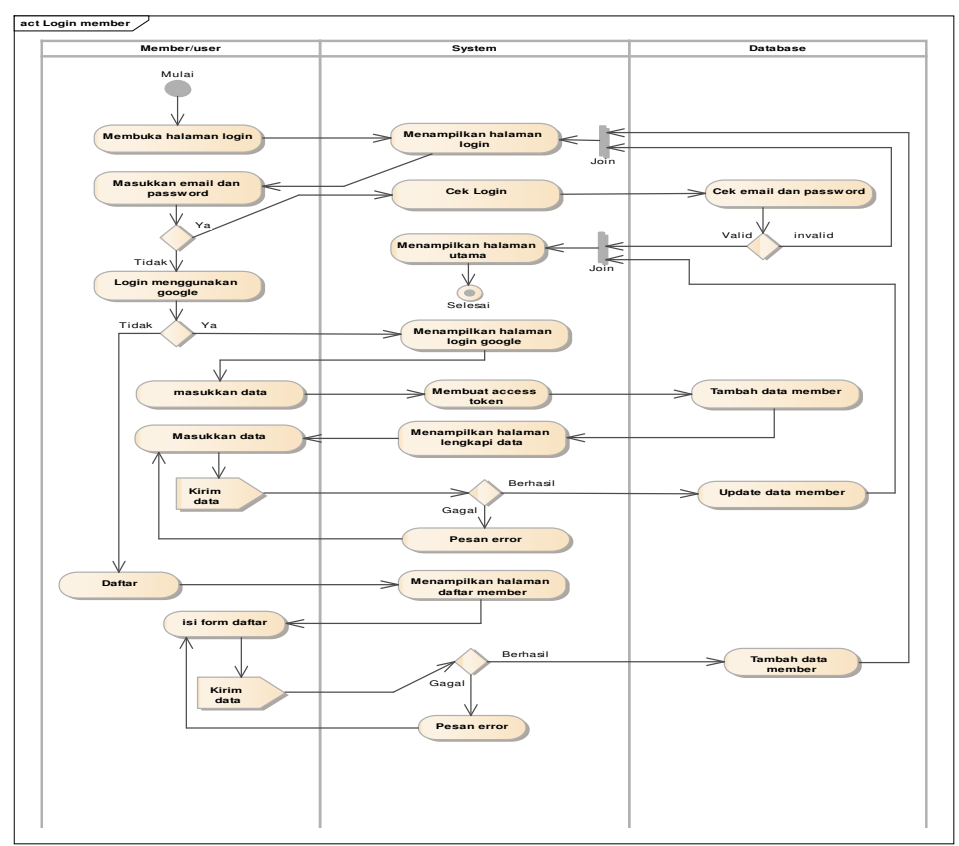

Gambar 2. Activity Diagram Login Member

d. Activity Diagram Belanja Online Halaman Member

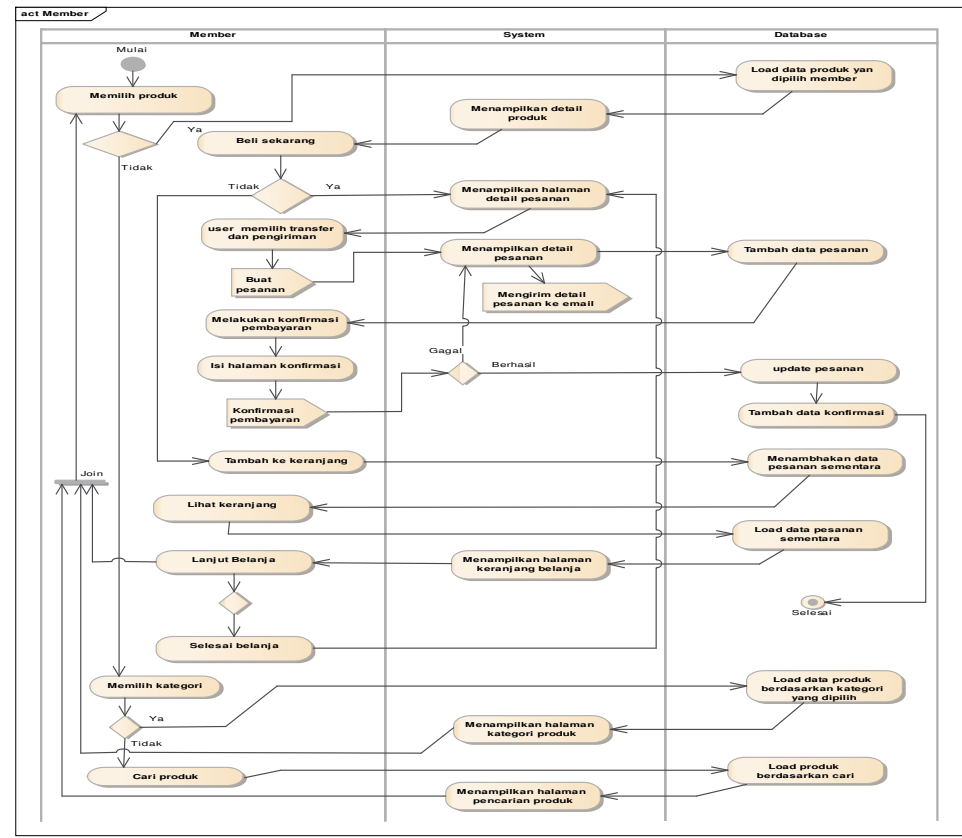

Gambar 3. Activity Diagram Belanja Online Member.

\subsection{Perancangan Model Sistem}

a. Entity Relation Diagram Penjualan online 


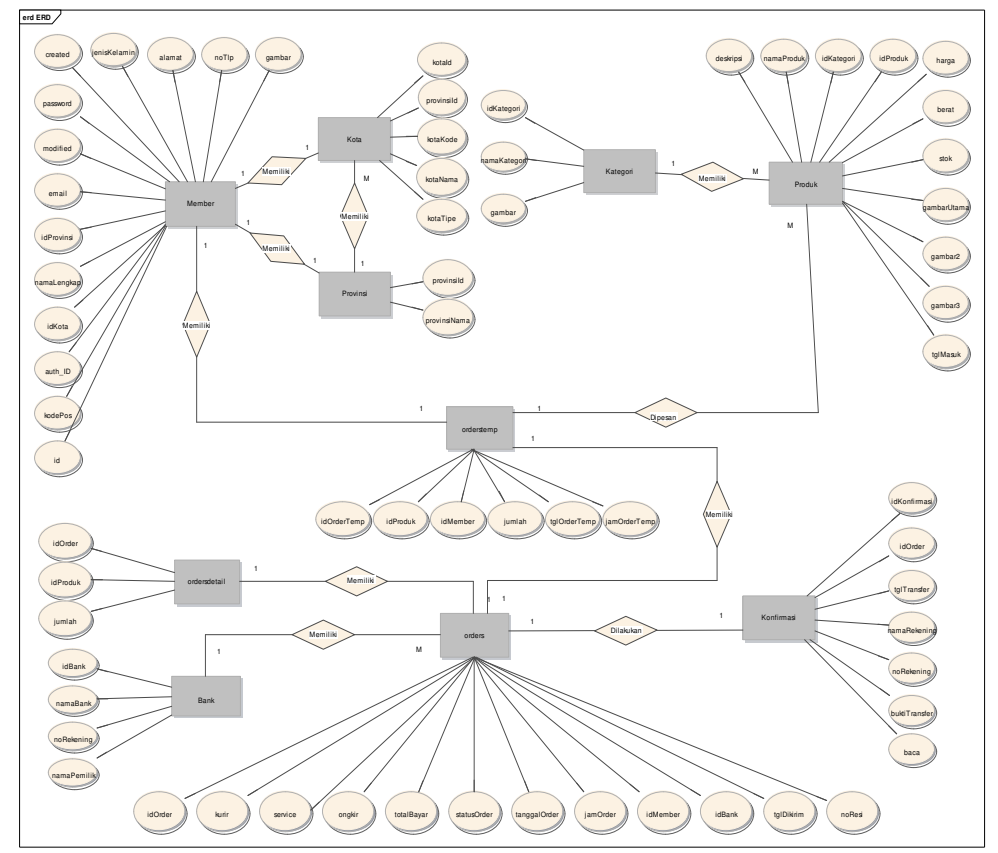

Gambar 4. Entity Relation Diagram Penjualan online

b. Logical record structure

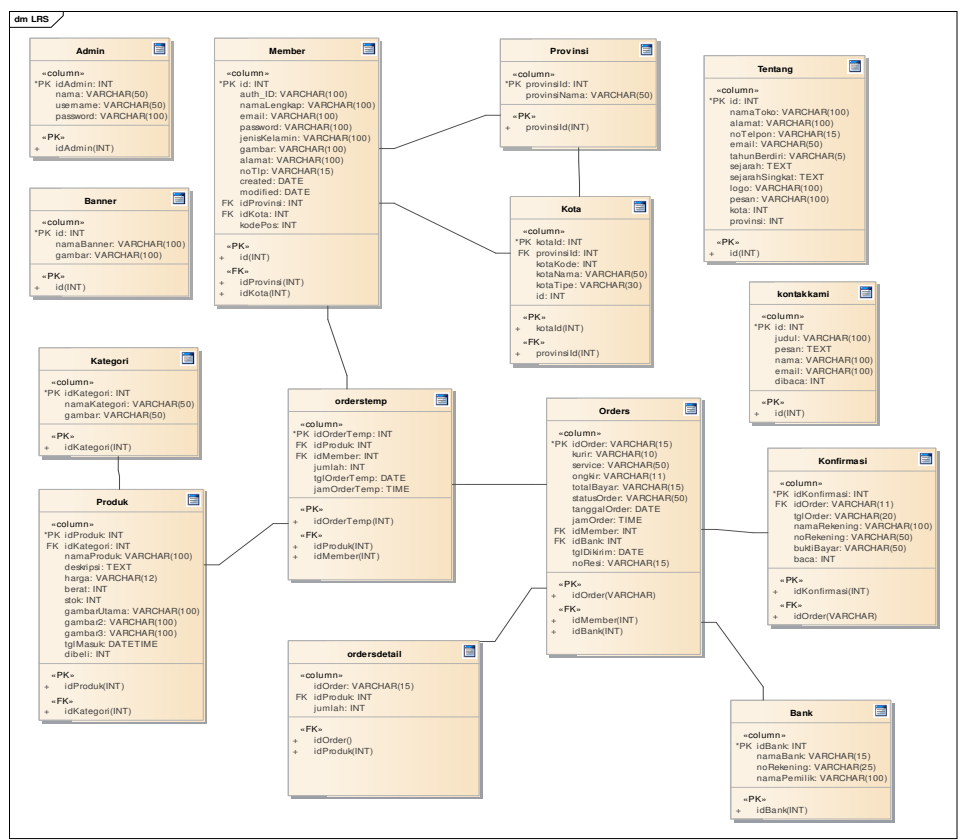

Gambar 5. Logical Record Structure

\subsection{Perancangan arsitektur perangkat lunak}

a. Class Diagram 


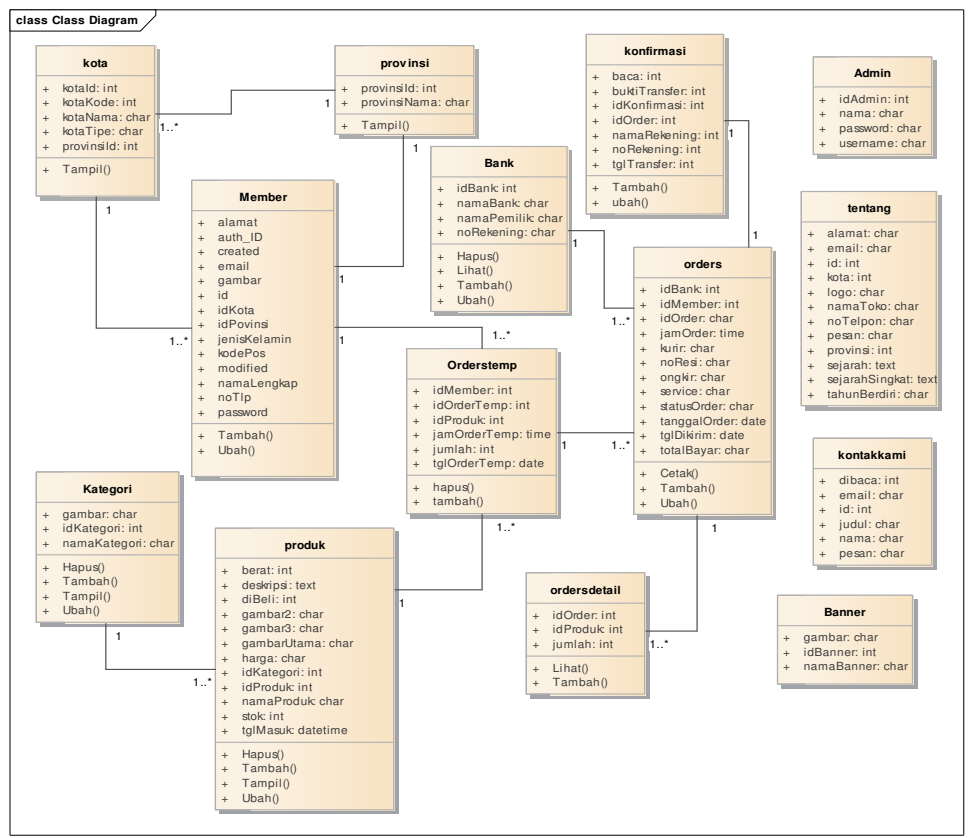

Gambar 6. Class Diagram

b. Sequence Diagram Member

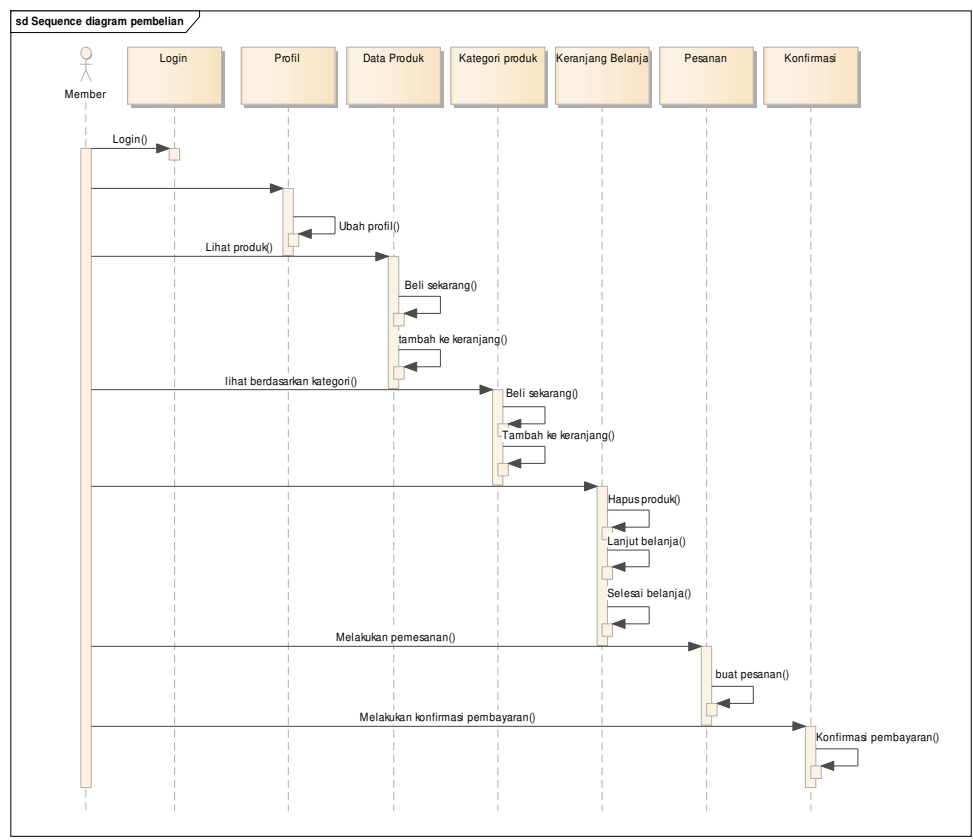

Gambar 7. Sequence Diagram Member

c. Deployment Diagram 


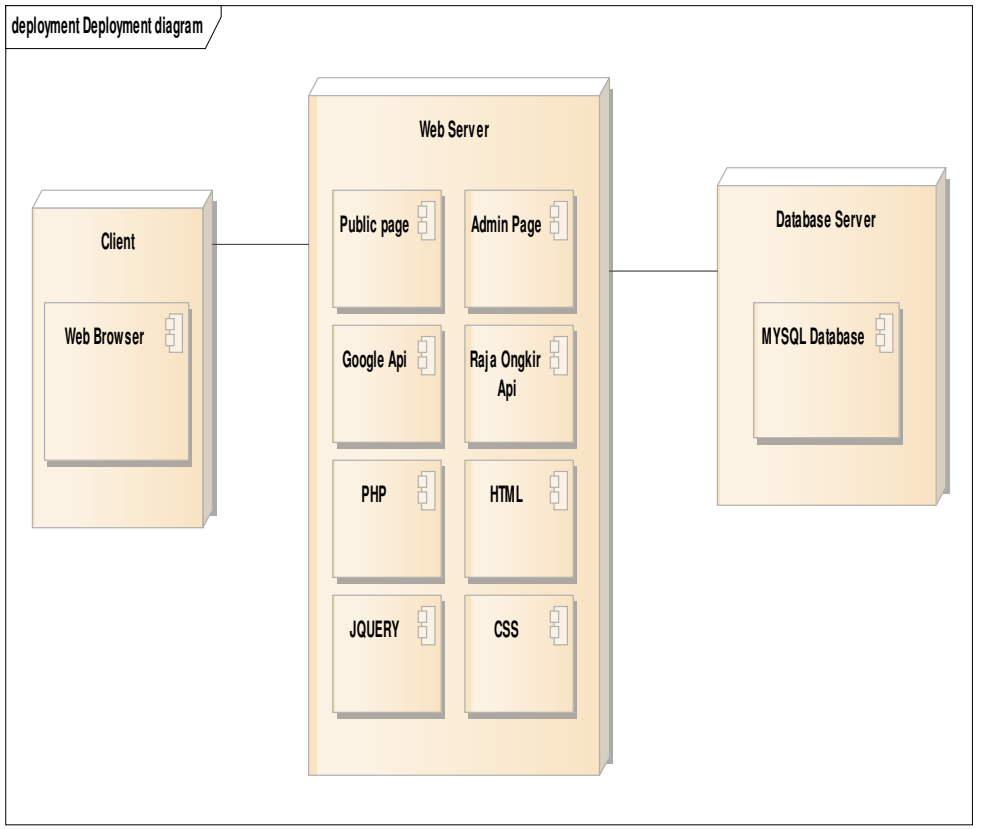

Gambar 8. Deployment diagram

\subsection{Perancangan Tampilan Antarmuka}

a. Daftar member

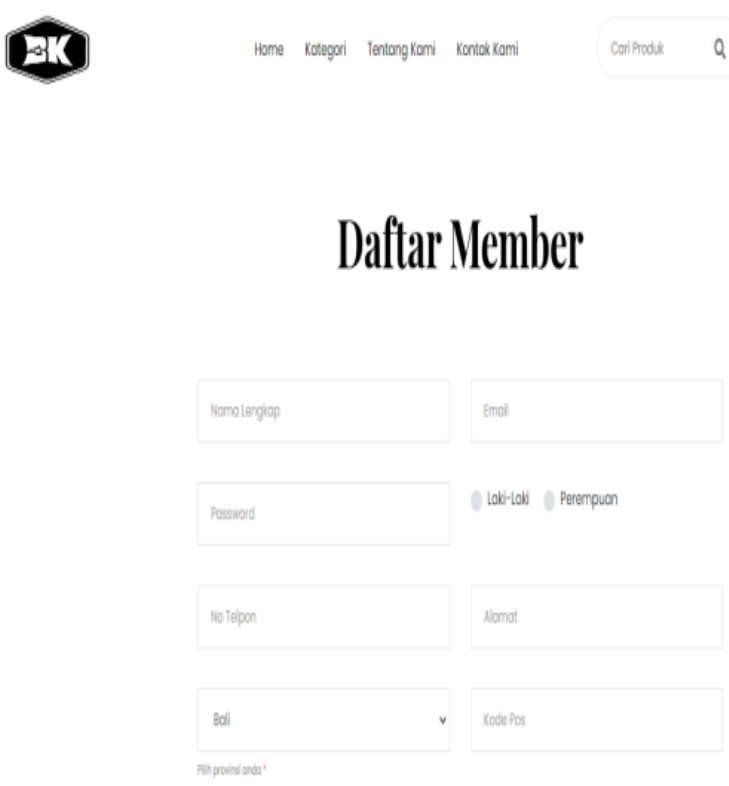

Gambar 9. Halaman Daftar Member

b. Login Member 

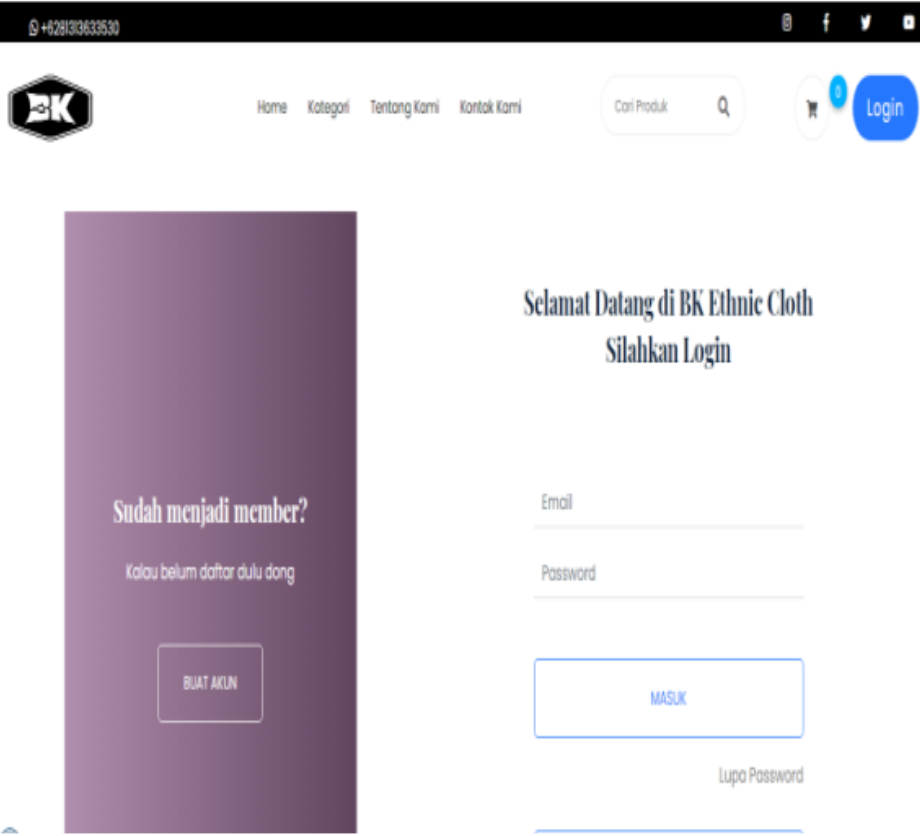

Selamat Datang di BK Ethnic Cloth

Silahkan Login

Gambar 10. Halaman Login Member

c. Keranjang Belanja Member

Q+6291316535300

\section{Keranjang Belanja}

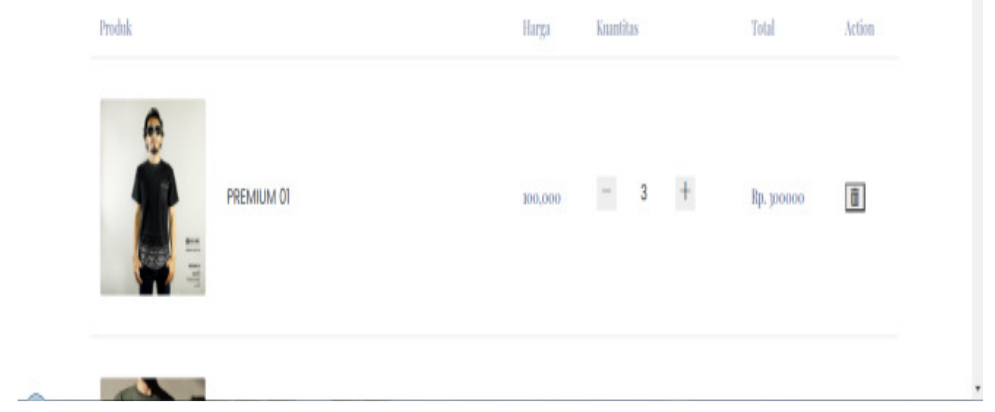

Gambar 11. Halaman Keranjang Belanja Member

d. Halaman checkout member 


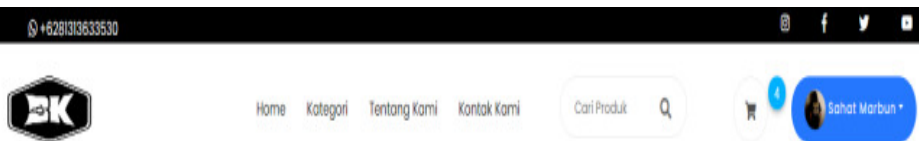

Pemesanan

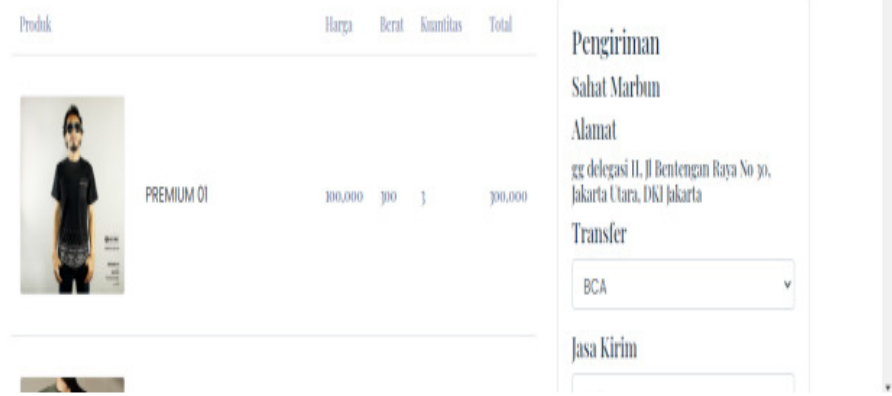

Gambar 12. Halaman Checkout Member

e. Halaman Detail Pesanan

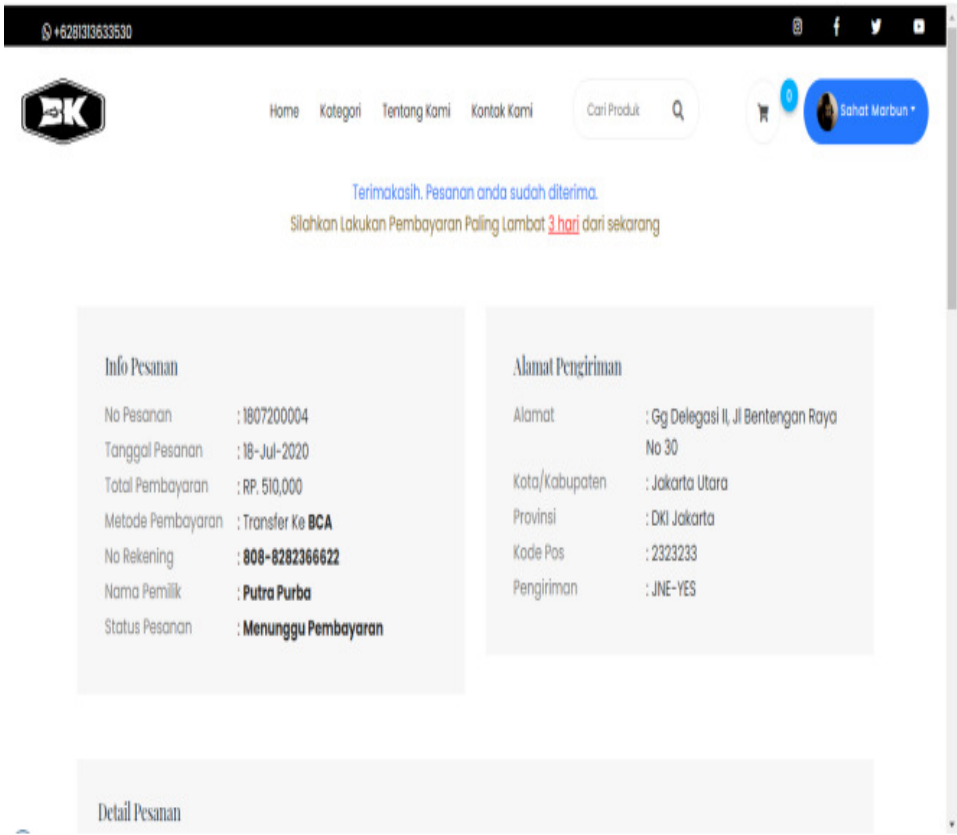

Gambar 13. Halaman Detail Pesanan

f. Halaman Konfirmasi Pembayaran 


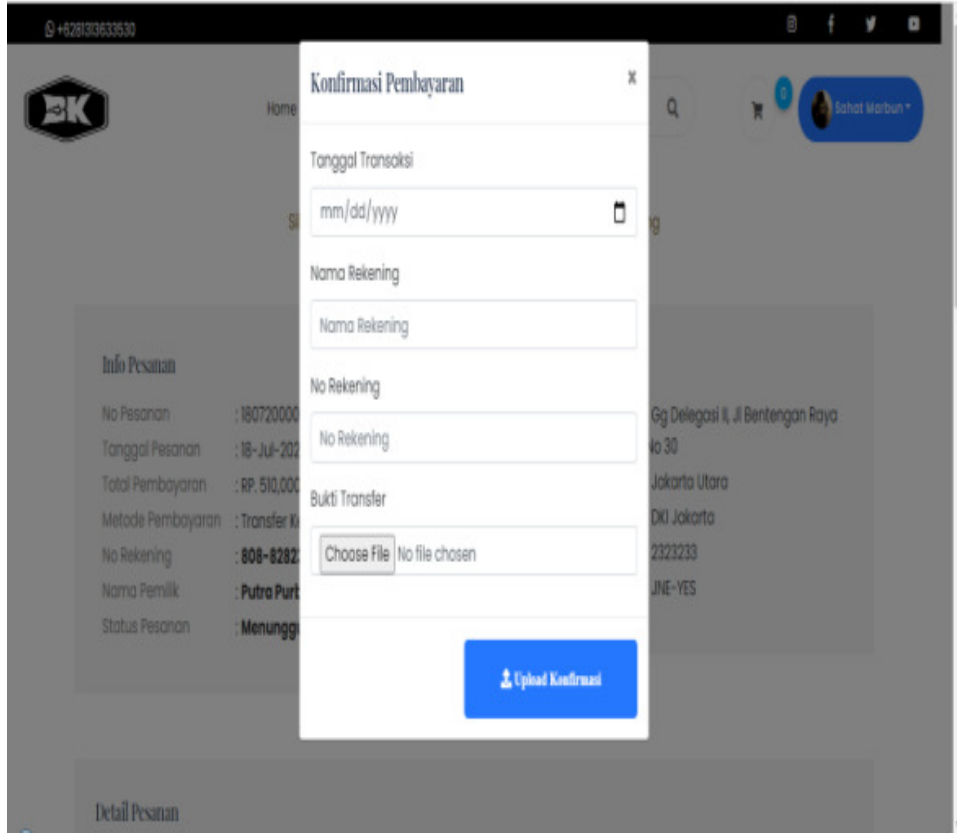

Gambar 14. Halaman Konfirmasi Pembayaran

\section{Kesimpulan}

Berdasarkan pembahasan di atas yang telah dibahas pada bab-bab sebelumnya, penulis yang berhubungan dengan pokok bahasan mengenai sistem informasi penjualan pada toko BK Ethnic Cloth adalah:

1. Terbatasnya pemasaran produk pada Toko BK Ethnic Cloth yang membuat persaingan menjadi tidak kompetitif dengan kompetitor lain. Sehingga dengan adanya sistem informasi penjualan ini dapat membantu toko dalam bersaing dan meningkatkan omset penjualan.

2. Proses transaksi penjualan masih menggunakan cara manual, hal ini membuat kinerja toko menjadi lama dan memakan waktu yang banyak. Dengan ada sistem informasi penjualan ini dapat membantu toko dalam mengolah transaksi sehingga lebih efektif dan efisien.

3. Kurangnya informasi ketersediaan produk membuat minat beli pelanggan berkurang, hal ini dapat menghambat tingkat penjualan produk. Dengan adanya sistem informasi penjualan dapat membuat pelanggan lebih mudah dalam melakukan permintaan akan produk.

4. Sistem informasi penjualan berbasis web ini dapat diakses oleh pelanggan dengan hanya melakukan pendaftaran, kemudian login, lalu memilih produk dan melakukan pemesanan. Pelanggan juga dapat menggunaan fitur pencarian untuk mempermudah pelanggan dalam memilih produk.

Aplikasi e-commerce BK EthnicCloth ini masih memiliki beberapa keterbatasan, sehingga penulis menyarankan untuk pengembangan aplikasi e-commerce ini sebagai berikut:

1. Proses pembayaran seharusnya dapat dilakukan dengan online misalnya menggunakan payment gateway seperti midtrans atau doku pay, sehingga proses konfirmasi pembayaran dapat di proses lebih cepat.

2. Menambahkan sistem keamanan agar data-data yang ada pada website lebih terjaga, seperti CSRF (Cross-side request forgery) dan XSS Filtering (Cross site scripting prevention filter).

\section{Daftar Pustaka}

[1] H. Hamdan, "INDUSTRI 4.0: PENGARUH REVOLUSI INDUSTRI PADA KEWIRAUSAHAAN DEMI KEMANDIRIAN EKONOMI," J. Nusant. Apl. Manaj. BISNIS, 2018, doi: 10.29407/nusamba.v3i2.12142.

[2] R. A. Pangondian, P. I. Santosa, and E. Nugroho, "Faktor-faktor yang mempengaruhi kesuksesan pembelajaran daring dalam revolusi industri 4.0," in Seminar Nasional Teknologi Komputer I\& Sains (SAINTEKS), 2019, vol. 1, 
no. 1.

[3] R. Rahayu and J. Day, "E-commerce adoption by SMEs in developing countries: evidence from Indonesia," Eurasian Bus. Rev., 2017, doi: 10.1007/s40821-016-0044-6.

[4] D. Zaliluddin and R. Rohmat, "PERANCANGAN SISTEM INFORMASI PENJUALAN BERBASIS WEB (STUDI KASUS PADA NEWBIESTORE)," Infotech J., 2018.

[5] T. Sutabri, Konsep sistem informasi. Penerbit Andi, 2012.

[6] D. Puspitasari, "RANCANG BANGUN SISTEM INFORMASI KOPERASI SIMPAN PINJAM KARYAWAN BERBASIS WEB," J. Pilar Nusa Mandiri, 2016.

[7] S. Maryama, "Penerapan E-Commerce Dalam Meningkatkan Daya Saing Usaha," Liquidity, 2018, doi: 10.32546/lq.v2i1.132.

[8] M. Ropianto, "Pemahaman Penggunaan Unified Modelling Language," Jt-Ibsi, 2016.

[9] D. Sukrianto, "Penerapan Teknologi Barcode pada Pengolahan Data Pembayaran Sumbangan Pembinaan Pendidikan (SPP)," Intra-Tech, 2017.

[10] R. V Palit, Y. D. Y. Rindengan, and A. S. M. Lumenta, "Rancangan Sistem Informasi Keuangan Berbasis Web Di Jemaat GMIM Bukit Moria Malalayang," E-Journal Tek. Elektro dan Komput. vol, 2015.

[11] I. WARMAN and R. RAMDANIANSYAH, "ANALISIS PERBANDINGAN KINERJA QUERY DATABASE MANAGEMENT SYSTEM (DBMS) ANTARA MySQL 5.7.16 DAN MARIADB 10.1," J. TEKNOIF, 2018, doi: 10.21063/jtif.2018.v6.1.32-41.

[12] I. Ripai, "Rancangan Bangn Media Pembelajaran Menggunakan Android Untuk Mata Kuliah Pemrograman Internet Menggunakan Magazine App Marker," J. ICT Learn., 2017.

[13] W. Hardyanto, A. Purwinarko, F. Sujito, D. Alighiri, and others, "Applying an MVC Framework for The System Development Life Cycle with Waterfall Model Extended," in Journal of Physics: Conference Series, 2017, vol. 824 , no. 1, p. 12007.

[14] O. Pedreira, "Creating Web-Based GIS Applications Using Automatic Code Generation Techniques," in Web and Wireless Geographical Information Systems: 15th International Symposium, W2GIS 2017, Shanghai, China, May 8-9, 2017, Proceedings, 2017, vol. 10181, p. 19.

[15] M. L. Larrea, "Black-box testing technique for information visualization. Sequencing constraints with low-level interactions," J. Comput. Sci. I\& Technol., vol. 17, 2017. 